Discussion Paper No. 08-131

Crime and the Labour Market: Evidence from a Survey of Inmates

Horst Entorf

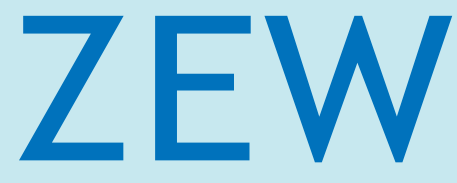

Zentrum für Europäische Wirtschaftsforschung $\mathrm{GmbH}$

Centre for European Economic Research 
Discussion Paper No. 08-131

\title{
Crime and the Labour Market: Evidence from a Survey of Inmates
}

\author{
Horst Entorf
}

Download this ZEW Discussion Paper from our ftp server:

ftp://ftp.zew.de/pub/zew-docs/dp/dp08131.pdf

Die Discussion Papers dienen einer möglichst schnellen Verbreitung von neueren Forschungsarbeiten des ZEW. Die Beiträge liegen in alleiniger Verantwortung der Autoren und stellen nicht notwendigerweise die Meinung des ZEW dar.

Discussion Papers are intended to make results of ZEW research promptly available to other economists in order to encourage discussion and suggestions for revisions. The authors are solely responsible for the contents which do not necessarily represent the opinion of the ZEW. 


\section{Nontechnical Summary}

Economists think that unemployment is an important cause for crime. From the theoretical point of view, this belief seems to be reasonable, since, according to the standard economic theory of crime by Nobel laureate Gary Becker , unemployed individuals are per definition excluded from legal income opportunities, and, thus, more likely to commit crimes than people who have a job. Empirical evidence is less clear. Econometric studies often show ambiguous signs for the effect of unemployment on crime. The main problem is the lack of adequate micro data. In this study based on a survey of 1,771 inmates conducted in 31 German prisons, the focus is on (expected) recidivism, not on criminal activity in general. Instead of re-contacting former inmates after their release (which would cause the problem of losing sight of most re-offending inmates), we interviewed prisoners about the perceived probability of their own future recidivism. Results show that inmates with poor labour market prospects expect a significantly higher rate of future recidivism. Having a closer look at subgroups of prisoners reveals that drug and alcohol addiction cause adverse effects. Thus, improving prisoner health care by installing effective anti-drug programmes would be one of the most effective measures against crime.

\section{Nicht-technische Zusammenfassung}

Ökonomen tendieren zu der Auffassung, dass Arbeitslosigkeit eine wichtige Ursache für kriminelles Verhalten darstellt. Aus theoretischer Sicht erscheint das plausibel, da entsprechend der Standardtheorie der Ökonomie der Kriminalität des Nobelpreisträgers Gary Becker Arbeitslosigkeit die legale Einkommenserzielung behindert und somit die Anreize zur illegalen Aktivität erhöht. Empirisch ist das Ergebnis weniger klar, was hauptsächlich an dem Mangel geeigneter Individualdaten liegt. In der vorliegenden Studie werden Befragungsdaten von 1.771 Haftinsassen verwendet, um den Aspekt der Rückfälligkeit zu untersuchen. Anstelle einer Befragung nach Haftentlassung (was aus Datenschutzgründen problematisch ist und einen Verlust an antwortwilligen und rückfälligen Probanden zur Folge hat), wurden Inhaftierte nach ihrer Rückfallerwartung interviewt. Die Ergebnisse der ökonometrischen Analyse zeigen, dass Insassen mit schlechter beruflicher Perspektive auch mit höherer Wahrscheinlichkeit befürchten, nach Haftentlassung rückfällig zu werden. Tiefergehende

Analysen von Tätergruppen offenbaren, dass insbesondere Alkohol- und Drogenabhängigkeiten negative Auswirkungen auf die erwartete Legalbewährung haben. Entsprechend dürfte beim Kampf gegen die Kriminalität ein effektives Antidrogenprogramm eines der wirkungsvollsten Mittel sein.

Key words: inmate survey, recidivism, labour market perspectives, discrete choice modelling JEL codes: J38, J68, C83, K42 



\title{
Crime and the Labour Market: \\ Evidence from a Survey of Inmates
}

\author{
Horst Entorf ${ }^{l}$ \\ Goethe University Frankfurt
}

This version: 23 January 2009

Abstract: In this paper data from a survey of 1,771 inmates conducted in 31 German prisons provide microeconometric evidence on the relationship between individual anticipated labour market opportunities and the perceived probability of future recidivism. Results show that inmates with poor labour market prospects expect a significantly higher rate of future recidivism. Having a closer look at subgroups of prisoners reveals that drug and alcohol addiction cause adverse effects. Thus, improving prisoner health care by installing effective anti-drug programmes would be one of the most effective measures against crime.

Corresponding Author:

\author{
Prof. Horst Entorf \\ Goethe University Frankfurt \\ Department of Economics \\ Grüneburgplatz 1 \\ D-60323 Frankfurt
}

Tel. (+49) 06979834765

entorf@,wiwi.uni-frankfurt.de

\footnotetext{
${ }^{1}$ I wish to thank two anonymous referees, Bernd Fitzenberger and Birgit Herrmann for very helpful comments and suggestions and the VolkswagenStiftung for research support.
} 


\section{Introduction}

The German economist Löwe (1914) ${ }^{2}$ was among the foremost researchers who study the relationship between unemployment and crime. Economists tend to believe that unemployment is one of the most important causes for crime. From the theoretical point of view, this belief seems to be reasonable, since, according to the economic theory of crime (Becker, 1968), unemployed individuals are per definition excluded from legal income opportunities, and, thus, ceteris paribus more likely to commit crimes than people who have a job. Or, put differently, unemployment will make crime more attractive if the alternative is a life in poverty (Eide, 2000). However, apart from this exclusively economic argumentation, unemployment might also have psychological consequences that foster delinquency. If, for example, unemployment is perceived as deeply unjust and society is held responsible for one's own misery, a break with social norms and, thus, a higher propensity for delinquent behaviour due to frustration might be the consequence. Good and Pirog-Good (1987) test frustration effects for black and white teenagers in the US and find that blacks apparently view employment and crime as alternative income-generating activities. They argue that reducing unemployment for high-risk black youths additionally reduces crime.

However, there also exists the opposite view that unemployment increases guardianship of home and (deviant) children and is thus decreasing the time spent in the 'unsafe' public. Moreover, the available loot would diminish.

Overall, the overwhelming majority of theoretical arguments suggest a positive relationship between unemployment and crime. Empirical evidence is less clear. Econometric studies often show ambiguous signs for the effect of unemployment on crime. The main problem is the lack of adequate micro data. Most studies are based on aggregate data such that individual characteristics cannot be controlled for. Thus, more studies based on individual data are needed. However, even with a survey on prisoners at hand, it is difficult to draw any general conclusion, because prisoners represent an adversely selected group of individuals who, in addition, are currently excluded from the markets of both legal and illegal activities.

\footnotetext{
${ }^{2}$ Adolf Löwe (1893 - 1995) was a professor of social sciences and economics at Kiel and at Goethe-University, Frankfurt. He emigrated from Germany in spring 1933 and took up a position at the University of Manchester. After leaving England in 1940, he joined the New School for Economic Research in New York City. There is an interesting line of connection from Adolf Löwe to Wolfgang Franz: Walter G. Hoffmann, University of Münster, was one of Löwe's students. Heinz König, doctoral advisor to Wolfgang Franz, was senior assistant to Walter G. Hoffmann and finished his habilitation thesis at Münster University. (Information provided by Harald Hagemann, University of Hohenheim: www.uni-hohenheim.de/wi-theorie/lowe.pdf)
} 
Therefore, in this study based on a survey of 1,771 inmates conducted in 31 German prisons, the focus is on (expected) recidivism, not on criminal activity in general. Instead of recontacting former inmates after their release (which would cause the problem of losing sight of most re-offending inmates), in this study we interviewed prisoners about the perceived probability of their own future recidivism. The potential influence of labour market prospects is tested by using information about self-reported contacts with potential employers for the time after release from custody. Given the high number of competing theories of crime and given the fact that many factors might simultaneously affect both labour market prospects and the inclination to engage in crime, the econometric results control for many observed individual characteristics such as category of offence, education, parental and family background, social capital, illicit drug use and alcohol problems.

Results show that inmates with a pessimistic appraisal of their job chances often expect their own future recidivism. Having a closer look at subgroups of prisoners reveals that such a relationship is mainly found for property crimes, while for inmates convicted for assault or sexual offences no significant effect of labour market contacts can be detected. The strongest covariate of recidivism, however, turns out to be drug and alcohol addiction.

This paper is organised as follows. Section 2 provides a brief review of the literature, in particular with respect to differences found for individual and aggregated data. Section 3 presents the data and highlights expected effects of important control variables. Econometric results are shown and discussed in Section 4. Section 5 concludes.

\section{Research on the Connection between Crime and the Labour Market}

There are many articles on the relationship between crime and the labour market, in particular on crime and unemployment. Several studies provide detailed surveys, see, among others, Chiricos (1987), Eide (1994, 2000), Entorf and Spengler (2002), Rupp (2008). Thus, the following chapter will only provide selected information, with focus on the crime-labour relationship based on individual (inmates) data, and on the observation that results might possibly be affected by the level of aggregation. The brief survey suffices for demonstrating that testing the labour market - crime nexus requires individual instead of aggregate data, in order to detect any true relationship. 
We start by focussing on empirical investigations at the individual level, since this is the level where crime decisions are made. A first impression can be derived from simple descriptive statistics. Holzman (1983), in a US study of habitual robbers and burglars based on the 1974 Survey of Inmates of State Correctional Facilities, reports that at the time of their latest offence approximately $25 \%$ offenders were unemployed. This is more than four times the US unemployment rate in the survey year (5.6 per cent). Tauchen, Witte and Griesinger (1994) report that adolescents who were employed for a larger percentage of a year are less likely to be arrested than those employed for a shorter percentage. However, these results may simply reflect the fact that the criminal population consists of people who are unable to succeed in society because of personal characteristics [which are] the cause of both the poor labor market record and criminal activity (Freeman, 1995). Freeman proposes detecting the causal effect of unemployment on crime by estimating labour supply relations between criminal participation and legal income opportunities (i.e. actual or predicted wages) and illegal income opportunities (i.e. criminal wages or perceptions of the attractiveness of crime). This way of research requires rarely available survey data, which have been collected within the 1980 National Bureau of Economic Research Inner City Youth Survey (see Freeman and Holzer, 1986). Viscusi (1986) summarizes his finding by stating youth who believe that they 'make more on the street than on a legitimate job' were far more likely to engage in crime than others and that estimated differences in income from crime and legitimate work also significantly affected crime behaviour, (Freeman, 1995). Weinberg et al. (2002) confirm this conclusion using individual data on unskilled workers in the U.S. While the general unemployment rate and wages have no significant effect on crime, local unemployment and wage development for this subgroup have a significant impact. Focussing on human capital, Lochner (2004) concludes that older, intelligent and educated people do commit less simple offences except for white collar crimes.

Quoted results are in accordance with results found for persons who went to jail and who reject work in favour of crime after their release. Sviridoff and Thompson (1983), who interviewed 61 adult male misdemeanants before and after their release, report a typical quotation that supports the economists' claim that crime is based on rational choice and on the weighting of the relative merits of risky crime and working life: They were making $\$ 200 a$ day in the street, $\$ 150$ a day, gambling, stealing. And now they gonna work, ten hours a day, seven days a week for \$ 125? (Sviridoff and Thompson, 1983). According to Sviridoff and Thompson, the problem with ex-offenders who were involved in property crime is that they seem to be particularly aware of crime and employment as competing alternatives. The 
problem is reinforced by their recent improvement of criminal capital at the expense of human capital. Thus, employment must be sufficiently profitable to be accepted. According to Sviridoff and Thompson (1983), this kind of calculus gives rise to alternation between employment and crime. They consider this behaviour to be the prevalent model for high-risk youths.

Turning to evidence based on aggregated data, Chiricos (1987) is one of the most prominent sources. He has carried out a large meta-study which investigates 288 estimates of the unemployment-crime relationship (UCR). Different levels of data-aggregation and the dimension of the data set provided give rise to what Chiricos referred to as the conditional nature of the UCR. As a rule, estimations relying on lower levels of data aggregation (e.g. city instead of state or national level data) and/or rather on cross-sectional than on time-series data, show higher frequencies of positive significance. 36 (14) \% of the time-series based property crime estimations considered by Chiricos (1987) show positive (negative) significant coefficients, whereas estimations relying on cross-sectional data never exhibit negative significance. Freeman (1995) doubts the reliability of time-series based assessments of the UCR, since all too often, addition of further observations or of another explanatory variable, or choice of statistical technique, substantively changes results. This instability of results of time-series investigations can be demonstrated by referring to the work of Entorf and Spengler (2000). Using a panel from 11 German states and covering a period of 22 years (i.e. with a dominant time-series dimension), two out of eight coefficient estimates of the unemployment rate showed negative significance and only one coefficient turned out to be positive and significant. Later in the paper, the authors tried another panel which has a dominant cross-sectional dimension (16 states, 4 years). Here six out of eight coefficients have turned out to be positive and significant, and no negative estimate remained. Raphael and Winter-Ebmer (2001) as well as Lee (2008) show that misspecification and omitted variable bias seem to lead to some general underestimation of the effect of unemployment on crime when time series data are used.

\section{Hypotheses and Data}

\subsection{Important Covariates and their Expected Effects on Crime}

As has been surveyed above, crime and labour market opportunities seem to be related, although there is no clear empirical evidence for the relationship between unemployment and 
crime. However, the criminological literature provides numerous further explanations for criminal behaviour such that several competing explanations of criminal behaviour need to be considered. In the social disorganisation (Shaw and McKay, 1942) and social control theory (Hirschi, 1969, Junger-Tas, 1992), factors based on family attachments have been revealed to be important causes for crime (see Entorf and Spengler, 2002, for more background information and empirical evidence for these theories). The main argument focusses on parental behaviour encouraging delinquency by setting a positive example or by failure to respond negatively to clearly deviant behaviour of the child (Hirschi, 1995).

The importance of delinquent peer relations for one's own criminal behaviour has been stressed by differential association (Sutherland, 1942) and interactional theory (Thornberry, 1996). Thornberry, Krohn, Lizotte and Chard-Wierschem (1993) find that entering a gang reinforces crime and leaving the gang reduces delinquency. However, if one considers peer relations other than delinquent ones ('good' friendships), the effect on criminal behaviour is expected to have the opposite direction. Particularly social control theory (Hirschi, 1969) stresses the crime-reducing effect of 'social attachment'. Social control theory is related to the concept of 'social capital' (Coleman, 1988). Social and human capitals help starting a regular career job and prevent involvement in criminal activities. Williams and Sickles (2000) confirm that accumulating social capital reduces (property) crime. Meyer (2007a) tests several measures of social capital and constructs social capital indices based on inherited and cumulated social capital. In general, her results are in accordance with the crime-reducing effect of social capital.

Recidivism is affected by the category-related typical frequency of crimes, i.e. the number of crimes per time period. Capital and most severe crimes such as murder or sexual offences occur with lower rates (but higher damage) than property crimes or drug related crimes. The same is most probably true for criminal careers after release from prison. In a cross-section, this observation implies that recidivism is expected to be higher for property and drug related crimes than for violent crimes. Hence, the econometric approach requires controlling for crime categories. Ignoring the crime-inherent frequency of offences might cause misleading or at least shaky conclusions, as high rates of recidivism typically found for property crimes such as theft might be interpreted as the negative outcome of ineffective reintegration policies and evidence for building criminal capital behind bars, whereas, for example, relatively lower rates for sexual offenders might be considered a success of performed treatment strategies. 


\subsection{Survey Data on the Retrospective and Current Situation of Inmates in Germany, and their Future Prospects}

This paper focusses on future behaviour of inmates and tests the hypothesis that labour market prospects (after being released from prison) are related to recidivism. Data used to test the hypothesis origin from a prison survey of 1,771 inmates. They were interviewed in 31 German prisons during the time period 2003 to 2004. The survey design followed a two-stage approach that combined stratified and random sampling (see Entorf, Meyer and Moebert, 2008, for details on the survey). In a first step, prisons were chosen such that the sample of prisons provides a representative sample of the population of all prisons in Germany. The stratification scheme was realised along the criteria 'region/ state' (i.e. regions represented by 'Bundesland') as well as the criteria 'number of prisons per 100,000 state inhabitants', 'prisoners per 100,000 state inhabitants', 'share of prisoners convicted according to adult (juvenile) penal law' and 'share of prisoners with a term equal and more (less than) two years'. The second step consisted of a random draw from the population of selected prisons. The survey was organized and performed by a team of researchers from Darmstadt University, the design of the questionnaire benefited from close cooperation with criminologists and practioners. ${ }^{3}$ As might be assumed from the delicate issue of interviewing prisoners behind bars, administrative barriers were quite high. For instance, interviews were only possible upon approval of the Departments of Justice of the respective states, and it was necessary to achieve compliance of local prison managers, to collect signed informed consents of prisoners who were selected to be interviewed, and it took lasting organisational work and cooperation with prison staff until the questionnaire could be handed over to the interviewee. In total, 13,340 questionnaires were distributed to the inmates of the sample of prisons. The finally available amount of 1,171 reasonably filled in questionnaires results in a response rate of $13.3 \%$.

Some additional interviews with judicial employees at visited prisons indicated that the representativity of the survey might be limited by the fact that the more 'active' group of prisoners has a higher probability of participation, while the more inactive and apathetic part of the prison population preferred to stay in their cells. This might have led to some underreporting of inmates with low education. Apart from education, comparisons with

\footnotetext{
${ }^{3}$ Preliminary versions of the questionnaire were thoroughly revised after pretests in Willich (North RhineWestphalia) and helpful meetings with judicial employees and Wolfgang Wirth from 'Kriminologischer Dienst NRW'.
} 
official statistics (mainly limited to demographic issues) show that the sample seems to provide a satisfactory picture of the German prison population. Detailed descriptive results on the survey can be gathered from Entorf, Meyer and Moebert (2008) as well as from Meyer $(2005,2007 a)$.

The variable of interest is 'expected recidivism'. It is constructed from the response to the following survey question: ${ }^{4}$

(1) Could it occur that after your release from custody you come into conflict with the law and end up in prison?

Tick your assessment on the following 5-point scale, whereby a 1 stands for "no, never", and a 5 stands for "absolutely certain":

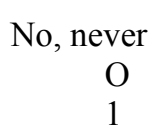

$\begin{array}{ll}\mathrm{O} & \mathrm{O} \\ 2 & 3\end{array}$

$\begin{array}{lc}\text { Absolutely certain } & \text { I'll be in again } \\ \mathrm{O} & \mathrm{O} \\ 4 & 5\end{array}$

The binary variable expected recidivism summarizes categories 3 to 5 . According to this definition, descriptive statistics from Table 1 reveal that $24 \%$ are not overly optimistic with respect to their future career outside prisons. The assessment of future legal labour market opportunities is based on a survey question on actual active job search:

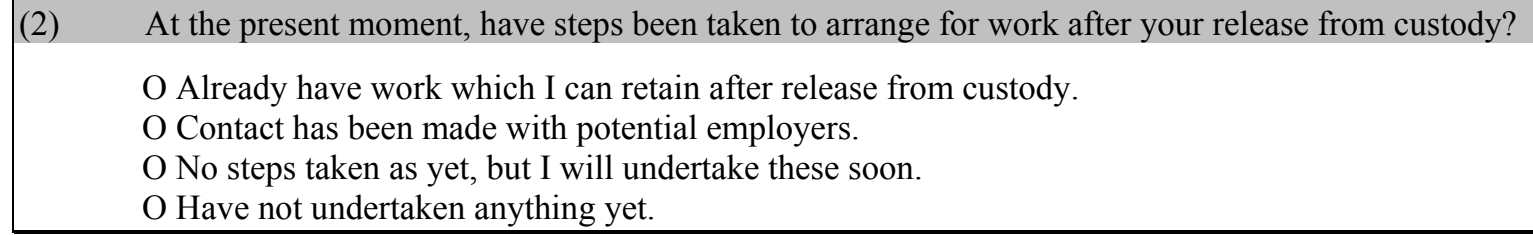

The majority of prisoners $(59.8 \%)$ have taken no steps, $40.8 \%$ respond that they had a job which could be retained after release (job expectation), or that contact has been made with potential employers (job contact).

Descriptive statistics of important additional criminological variables are listed in Table 1. Family background is captured by the dummy variable criminal family background. It documents any criminal record of father, mother, brothers or sisters. The social bonds due to close interaction with spouses and partners are represented by married and frequent contact with partner. Only $17.9 \%$ of inmates are married.

\footnotetext{
4 The survey was distributed in either German or Turkish, Serbo-Croatian, Russian, Polish and English language.
} 


\begin{tabular}{|c|c|c|c|c|c|}
\hline Variable & Obs & Mean & Std. Dev. & Min & Max \\
\hline $\begin{array}{l}\text { expected recidivism } \\
(1=\text { recidivism is considered } \\
\text { being likely, } 0=\text { if not })\end{array}$ & 1627 & .237 & .425 & 0 & 1 \\
\hline $\begin{array}{l}\text { job expectation } \\
\text { ( } 1 \text { if respondent has job } \\
\text { which can be retained after } \\
\text { release, } 0 \text { otherwise) }\end{array}$ & 1627 & .203 & .402 & 0 & 1 \\
\hline $\begin{array}{l}\text { job contact } \\
\text { ( } 1 \text { if contact has been made } \\
\text { with potential employers, } \\
0 \text { otherwise) }\end{array}$ & 1627 & .205 & .404 & 0 & 1 \\
\hline age & 1568 & 33.68 & 10.48 & 16 & 59 \\
\hline male & 1627 & .890 & .313 & 0 & 1 \\
\hline Schooling: & & & & & \\
\hline - no school & 1627 & .126 & .332 & 0 & 1 \\
\hline - 'Hauptschule' & 1627 & .446 & .497 & 0 & 1 \\
\hline - 'Realschule' & 1627 & .179 & .384 & 0 & 1 \\
\hline - 'Fachoberschule' & 1627 & .071 & .257 & 0 & 1 \\
\hline - 'Abitur' & 1627 & .098 & .297 & 0 & 1 \\
\hline Occupational status: & & & & & \\
\hline - unskilled worker & 1627 & .394 & .489 & 0 & 1 \\
\hline - vocational training & 1627 & .494 & .500 & 0 & 1 \\
\hline - university & 1627 & .075 & .263 & 0 & 1 \\
\hline Crime categories: & & & & & \\
\hline - theft & 1627 & .245 & .430 & 0 & 1 \\
\hline $\begin{array}{l}\text { - drug dealing or } \\
\text { consumption }\end{array}$ & 1627 & .202 & .402 & 0 & 1 \\
\hline - fraud & 1627 & .197 & .398 & 0 & 1 \\
\hline - $\quad$ assault & 1627 & .196 & .397 & 0 & 1 \\
\hline - robbery & 1627 & .145 & .322 & 0 & 1 \\
\hline - sexual offence & 1627 & .101 & .302 & 0 & 1 \\
\hline
\end{tabular}




\begin{tabular}{|c|c|c|c|c|c|}
\hline Variable & Obs. & Mean & Std. Dev. & Min & Max \\
\hline - murder/manslaughter & 1627 & .098 & .297 & 0 & 1 \\
\hline - vandalism & 1627 & .020 & .139 & 0 & 1 \\
\hline - other crime & 1627 & .173 & .379 & 0 & 1 \\
\hline $\begin{array}{l}\text { being addicted to alcohol } \\
\text { /drugs }\end{array}$ & 1627 & .314 & .464 & 0 & 1 \\
\hline $\begin{array}{l}\text { criminal family background } \\
\text { ( } 1 \text { if father, mother, brother } \\
\text { or sister have criminal record) }\end{array}$ & 1627 & .169 & .375 & 0 & 1 \\
\hline married & 1627 & .179 & .384 & 0 & 1 \\
\hline $\begin{array}{l}\text { frequent contact with partner } \\
(1=\text { once a week or more })\end{array}$ & 1627 & .525 & .499 & 0 & 1 \\
\hline $\begin{array}{l}\text { poor social capital } \\
\text { ( } 1 \text { if no membership in } \\
\text { club, political party etc.) }\end{array}$ & 1627 & .567 & .496 & 0 & 1 \\
\hline Interactions: & & & & & \\
\hline - $\quad$ theft $\times$ abitur & 1627 & .014 & .118 & 0 & 1 \\
\hline - $\quad d r u g s \times$ abitur & 1627 & .017 & .130 & 0 & 1 \\
\hline - fraud $\times$ abitur & 1627 & .033 & .179 & 0 & 1 \\
\hline - robbery $\times$ abitur & 1627 & .009 & .096 & 0 & 1 \\
\hline - $\quad$ assault $\times$ abitur & 1627 & .009 & .096 & 0 & 1 \\
\hline - $\quad$ theft $\times$ job $b^{l}$ & 1627 & .089 & .284 & 0 & 1 \\
\hline - $\quad d r u g s \times j o b^{l}$ & 1627 & .078 & .268 & 0 & 1 \\
\hline - fraud $\times j o b^{1}$ & 1627 & .108 & .311 & 0 & 1 \\
\hline - $\quad$ robbery $\times j o b^{l}$ & 1627 & .067 & .250 & 0 & 1 \\
\hline - $\quad$ assault $\times j o b^{l}$ & 1627 & .097 & .335 & 0 & 1 \\
\hline
\end{tabular}

Notes: Dummy variables are set equal to 1 if expressions are true, 0 otherwise. Except for 'expected recidivism', realisations with value 0 might cover missing values. The common sample is restrained by the validity of data for 'expected recidivism'. ') ' $\mathrm{job}=1$ ' $\equiv$ 'job expectation $=1$ ' .or. 'job contact $=1$ ' (and 'job $=0$ ' otherwise). 
Human capital background (in ascending order of educational degrees) is captured by no school, 'Hauptschule', 'Realschule', 'Fachoberschule' and 'Abitur' and, in addition, by the occupational status of inmates. The latter is covered by the categories 'unskilled worker', (completed) 'vocational training' and 'university'. Even though self-selection mechanisms might have favoured the presence of more active and possibly more educated respondents, comparisons with official statistics of the German resident population (see Meyer, 2007b) confirm a relatively poor human capital background of the majority of prison inmates, as can be seen, for instance, from the share of $39.3 \%$ responding not to have completed any professional education. ${ }^{5}$

Following Knack and Keefer (1997), Putnam (1993, 2000) and others, social capital is measured by membership in clubs (sports, hobby etc.), poor social capital is equal to 1 if no membership has been recorded.

Further control variables refer to gender, age, alcohol and drug addiction, and the crimes committed by inmates. The largest groups consist of theft $(24.5 \%)$, drug offences $(20.2 \%)$, fraud (19.7\%), and assault (19.6\%) (note that the sum over all crime categories exceeds $100 \%$ as inmates might be committed for more than one single crime). As can be seen from the ratio of males, the prison population is mainly male. The percentage share of $11 \%$ of females in the sample is even somewhat more elevated than in the German prison population, where it amounts to $5.5 \%$ (2006). The age distribution is limited to inmates under 60 years of age (because of the labour market issue analysed in this paper).

One of the most striking problems of German prisons is the high proportion of inmates being addicted to alcohol, illicit drugs or both: $31 \%$ respond that they consider themselves to be addicted or 'having serious problems' with alcohol or drugs. This high percentage corresponds with the large share of inmates being convicted due to drug offences (drug dealing or consumption), not counting convictions indirectly related to drug or alcohol abuse such as theft, or violent acts which are committed under the influence. ${ }^{6}$

Looking at interactions of variables of interest, there are some regularities which need some deeper investigation in the subsequent econometric analysis. For instance, job chances (covered by job expectation or job contact) seem to be relatively good for inmates convicted for fraud $(10.8 \%$ out of $19.7 \%)$, in particular when compared to drug offences $(7.8 \%$ out of

\footnotetext{
${ }^{5}$ Table 1 does not include the share of respondents with missing data on their professional status $(3.7 \%)$.

${ }^{6}$ A large share of thefts is committed by drug addicts who need to finance their habits; see Entorf and Winker (2008) for description and macroeconomic analysis of the drugs-crime channel.
} 
$20.2 \%$ ). This first impression is confirmed by schooling, as $3.3 \%$ out of $19.7 \%$ of the inmates (i.e.16.8\% of all inmates convicted for fraud) have achieved the highest educational degree 'Abitur'. This high ratio is in sharp contrast to other crime categories such as drug offence $(8.4 \%=1.7 / 20.2)$ and particularly assault $(4.6 \%=0.9 / 19.6)$.

\section{Results}

Table 2 presents results of Probit estimations. ${ }^{7}$ The first column provides results for all variables presented above, the second column also includes interaction terms, and in the third column regressions are repeated excluding parameters which were found insignificant ( $p$ values above $10 \%$ ) in column (2). Marginal effects of these final results are presented in column (4).

From Table 2, column (1), we observe that good labour market prospects are negatively associated with self-assessed future recidivism. Both categories, i.e. job expectation and job contacts are highly significant at the $1 \%$-level. Only gender seems to be of equal or even higher importance: Female prisoners expect much smaller recidivism rates than their male counterparts.

Some inmate characteristics evidently hinder legal labour market careers. For example, drug and alcohol addiction and previous careers in drug dealing provide strong incentives to revive old customs. Adverse family background (any criminal record in a family) has the expected positive sign, but the effect is not significant. The same (with expected negative sign) holds for social capital measured by membership in clubs as well as for 'married'. It seems that it is not the mere fact of marriage per se which is important for rehabilitation; the fact that active partnerships are experienced is more important and plays a significant role (see frequent contact with partner).

Somewhat surprising is the insignificant role of human capital variables. Only 'Abitur' has the expected negative sign, but the p-value is above conventional significance levels ('Realschule', 'Hauptschule', 'other school', no school and missing schooling information

\footnotetext{
${ }^{7}$ Given the ordered categories of the survey question, ordered discrete choice models would have been the natural alternative to the performed binary response model. The reason for using ordinary Probit is the rather small number of observations in Table 3 where the same model is also applied for sub-samples consisting of major crime categories. Summarizing categories prevents misinterpretations of subjective survey questions and avoids problems arising from sparsely filling in certain survey categories, in particular due to the often found rare use of extreme survey categories.
} 
represent the reference category for schooling, estimated parameters on 'occupational status' have to be interpreted relative to 'unskilled worker' and 'occupation missing'). The reason might be seen in the adverse selection of a particular group of individuals into prisons. For them their relatively high human capital does not provide any incentive to deviate from a deliberately chosen illegal career. ${ }^{8}$ An alternative interpretation is that inmates with low education are overly optimistic with respect to their future legal opportunities such that differences between low and high human capital turn out being insignificant.

As regards the types of offenders, criminals convicted for property crimes express a higher expectation of being re-imprisoned than violent criminals. ${ }^{9}$ The reason is threefold. First, as detailed in Section 3.1, property crimes can be considered as more frequent (and, in general, less harmful) delinquencies than violent crimes such that recidivism rates of theft, drug offences etc. are expected to be higher than for murder, sexual offences etc. Second, property crimes are partly motivated by drug addiction, such that the same arguments mentioned in the previous paragraph hold once again. The third point, however, is related to the traditional trade-off between legal and illegal income opportunities in the economics of crime: Theft and fraud can be viewed as typical examples of rational choice behaviour. Hence, given education, criminal record, experience etc., this group might consider future illegal careers, including potential re-imprisonment, as superior alternatives to legal careers.

In order to distinguish the economic motivation for property-crime recidivism from other reasons, Table 2, column (2), considers interaction effects for theft, robbery, fraud and drug offences with individual education (captured by the highest educational degree, i.e. 'Abitur'), and with reported inmates' job market opportunities, measured by job (job is equal to 1 if inmates report positive job expectations or if job contacts have been made). Results will be subsequently complemented by econometric results for major crime categories (see Table 3).

Table 2, column (2) confirms previous significant findings concerning legal labour market opportunities, gender, drug and alcohol addiction, and frequent contact with partner. Given newly introduced interactions with crime categories, parameter estimates on education (covered by 'Abitur') and job opportunities (summarized by job) cannot be directly compared to results in Table 2, column (1), as part of the former total effect now reappears as cross

\footnotetext{
${ }^{8}$ This hypothesis will be analysed in more detail in Table 2, column (2), where interaction terms between education and type of offender are considered (see below).

${ }^{9}$ Violent crimes (assault, murder and manslaughter, and sexual offences) are omitted from the regression, i.e. they represent the reference category for included crime categories.
} 
effect. Calculating conventional parameter estimates and standard errors, two interaction terms show significant effects at the 5\% level, of which the most striking one is the positive effect found for thieves who completed Gymnasium. However, interpretation of interaction effects in non-linear Probit models is different from the usual interpretation of (marginal) effects in Probit or Logit models or the interpretation of interaction parameters in linear regression models, because additional effects from second derivatives have to be taken into account (see $\mathrm{Ai}$ and Norton, 2003, for details). We thus checked significance, sign and marginal effects using complementary linear probability models (results not reported). They confirm results presented in Table 2, columns (2) and (3). Marginal LPM interaction effects, too, are found similar to results presented in column (4) (theft $\times$ abitur: 0.23 , drugs $\times$ job: -0.14 , all other interaction effects were confirmed as being insignificant).

The elevated probability of recidivism for thieves with higher education confirms and refines conjectures about self-selected highly educated individuals in prison. They might be rather well described as crime-prone rational-choice offenders - something indeed often ascribed to criminals committing property crimes - who behave quite differently from usual legal workers for whom better education would decrease the inclination to crime.

The second significant ${ }^{10}$ interaction is found for drugs $\times$ job. Contrary to the large and positive, i.e. recidivism enhancing (main) effect of being convicted for drug offences, drug offenders are much more optimistic about their future life when they have good labour market prospects. However, descriptive statistics have shown that this only holds for a minority of all imprisoned drug offenders.

Many parameters in column (2) of Table 2 have proven insignificant. Column (3) presents Probit estimates based on specifications which retain only those variables being significant at least at the $10 \%$ level. Corresponding average partial effects are presented in column (3'). Resulting final estimates confirm the preliminary conclusions based on columns (1) and (2), with one important exception. While (the main effect of) 'Abitur' is insignificant in columns (1) and (2), now higher education (measured by 'Abitur') significantly reduces the risk of recidivism. Thus, taking account of the complexity of the relationship between education and recidivism by considering the diversity of crime categories uncovers expected human capital effects.

\footnotetext{
${ }^{10}$ Significance cannot be solely judged on the grounds of conventional parameter estimates and standard errors (see Ai and Norton, 2003), but is confirmed using additional LPM modelling (see above).
} 
Table 3 depicts results by crime category. Only final estimations leading to p-values below $10 \%$ are shown. Interaction results in Table 2 suggest that better education ('Abitur') increases recidivism of thieves. This result is confirmed in Table 3, albeit in a weakly significant way. For the remaining property crimes, the sign is negative. It seems that among property crimes, theft is surprisingly different from other categories. However, one has to keep in mind that results for theft are based on just 23 observations with "abitur $=1$ " such that more evidence is needed before strong conclusions could be drawn.

Results differ for the impact of education on violent crimes: Here no effect whatever is detected.

For other factors, too, there are interesting differences between property and violent crimes. The crime curbing effect of advantageous labour market prospects seems to be mainly limited to property crimes: significant results (at the 5\% level) are found for theft, fraud and robbery, whereas no such effect has been found for assault, and sexual offences. The strongest effect is estimated for drug offences (as already stated by use of interaction effects in Table 2).

Drug and alcohol addiction play crucial roles for recidivism. Once again, this result is clearly confirmed for 5 out of 7 crime categories.

Drug abuse might also have indirect effects. Drug addiction often causes property crimes; they provide the financial means necessary to finance expensive drug consumption. Many violent crimes, too, are committed under the influence of illicit drugs or alcohol. The econometric results reflect these arguments. A certain number of inmates are convicted for more than one crime. If drug dealing or consumption is the second (or, more general, 'further') crime, then it is likely that the true background of the first major crime is drug or alcohol addiction. It is thus not surprising that for all but one crime category (sexual offences) the existence of drug offences as further crime increases the subjective risk of recidivism.

In particular understanding the motivation of inmates imprisoned for assault is of current public interest in Europe, where assault rates are steadily increasing since the early 1990s. Results from Table 3 suggest that significant factors of violent assaulters diverge from the characterization of other types of criminals. Assault is the only crime category where the adverse parental and family background is of clear importance. Also 'contact with partner' and 'social capital' are weakly significant. Age has a negative sign, reflecting the worse prospects of younger inmates. This might indicate their frustration and the dissatisfaction with their current situation. Frustration and the perception of injustice are shown to be crime enhancing factors (see Good and Pirog-Good, 1987). They behave similarly to the group of 
'discouraged workers' (see Franz, 1982) on the legal labour market, who do not believe that that the labour office or any rehabilitation system is able to provide a legal job offer for them. All these effects show that assault can hardly be described as a 'rational' act. This type of offenders rather acts on the spur-of-the-moment, motivated by frustration and social exclusion. Problems are reinforced by alcohol and illicit drug abuse, as found almost everywhere.

Modelling and predicting recidivism of sexual offenders, finally, seems to be impossible, at least given the set of variables at hand. No single factor turns out to be significant at the $10 \%$ level. The reason might be seen in the nature of sexual offences which often have their roots in a sexual deviation such that the probability of recidivism depends on successful sexual therapy rather than other criminological or economic factors. 
Table 2: Probit Estimates

(3')

\begin{tabular}{|c|c|c|c|c|}
\hline Expected Recidivism & (1) & $(2)$ & (3) & $(\mathrm{dF} / \mathrm{dx})$ \\
\hline Job expectation & $\begin{array}{c}-0.395 * * \\
(0.105)\end{array}$ & - & - & - \\
\hline Job contacts & $\begin{array}{c}-0.361^{* *} \\
(0.097)\end{array}$ & - & - & - \\
\hline Job expected or contacted & - & $\begin{array}{l}-0.238^{*} \\
(0.119)\end{array}$ & $\begin{array}{c}-0.277 * * \\
(0.088)\end{array}$ & $\begin{array}{c}-0.076^{* *} \\
(0.022)\end{array}$ \\
\hline Female & $\begin{array}{c}-0.372 * * \\
(0.125)\end{array}$ & $\begin{array}{c}-0.380^{* *} \\
(0.125)\end{array}$ & $\begin{array}{l}-0.400^{* *} \\
(0.123)\end{array}$ & $\begin{array}{c}-0.099 * * \\
(0.036)\end{array}$ \\
\hline Age & $\begin{array}{l}-0.006 \\
(0.004)\end{array}$ & $\begin{array}{l}-0.003 \\
(0.004)\end{array}$ & - & - \\
\hline 'Abitur' & $\begin{array}{l}-0.131 \\
(0.142)\end{array}$ & $\begin{array}{l}-0.250 \\
(0.241)\end{array}$ & $\begin{array}{r}-0.386^{*} \\
(0.164)\end{array}$ & $\begin{array}{c}-0.095^{* *} \\
(0.034)\end{array}$ \\
\hline 'Fachoberschule' & $\begin{array}{c}0.158 \\
(0.154)\end{array}$ & - & - & - \\
\hline $\begin{array}{l}\text { Medium or high skilled worker } \\
\text { (apprenticeship/university) }\end{array}$ & $\begin{array}{c}0.131 \\
(0.086)\end{array}$ & - & - & - \\
\hline Alcohol/drugs addiction & $\begin{array}{c}0.506^{* *} \\
(0.080)\end{array}$ & $\begin{array}{c}0.498^{* *} \\
(0.080)\end{array}$ & $\begin{array}{c}0.512 * * \\
(0.078)\end{array}$ & $\begin{array}{c}0.154 * * \\
(0.027)\end{array}$ \\
\hline Crime $=$ vandalism & $\begin{array}{c}0.155 \\
(0.250)\end{array}$ & $\begin{array}{c}0.153 \\
(0.254)\end{array}$ & - & - \\
\hline Crime $=$ theft & $\begin{array}{c}0.278^{* *} \\
(0.088)\end{array}$ & $\begin{array}{l}0.201 \\
(0.107)\end{array}$ & $\begin{array}{c}0.252^{* *} \\
(0.083)\end{array}$ & $\begin{array}{c}0.073 * * \\
(0.027)\end{array}$ \\
\hline $\begin{array}{l}\text { Crime }=\text { drug dealing/ } \\
\text { consumption }\end{array}$ & $\begin{array}{c}0.338 * * \\
(0.091)\end{array}$ & $\begin{array}{c}0.491 * * \\
(0.117)\end{array}$ & $\begin{array}{c}0.467 * * \\
(0.109)\end{array}$ & $\begin{array}{c}0.141 * * \\
(0.036)\end{array}$ \\
\hline Crime $=$ fraud & $\begin{array}{c}0.178 \\
(0.098)\end{array}$ & $\begin{array}{c}0.254 \\
(0.133)\end{array}$ & $\begin{array}{c}0.161 \\
(0.096)\end{array}$ & $\begin{array}{c}0.046 \\
(0.028)\end{array}$ \\
\hline Crime $=$ robbery & $\begin{array}{l}0.103 \\
(0.104)\end{array}$ & $\begin{array}{c}0.161 \\
(0.136)\end{array}$ & - & - \\
\hline Crime $=$ 'other crime' & $\begin{array}{c}0.061 \\
(0.101)\end{array}$ & $\begin{array}{c}0.069 \\
(0.101)\end{array}$ & - & - \\
\hline Criminal family background & $\begin{array}{c}0.129 \\
(0.095)\end{array}$ & $\begin{array}{c}0.119 \\
(0.095)\end{array}$ & - & - \\
\hline Married & $\begin{array}{l}-0.160 \\
(0.106)\end{array}$ & $\begin{array}{l}-0.164 \\
(0.106)\end{array}$ & $\begin{array}{l}-0.197 * \\
(0.102)\end{array}$ & $\begin{array}{l}-0.052^{*} \\
(0.026)\end{array}$ \\
\hline Frequent contact with partner & $\begin{array}{c}-0.184^{*} \\
(0.075)\end{array}$ & $\begin{array}{c}-0.178^{*} \\
(0.075)\end{array}$ & $\begin{array}{c}-0.163 * \\
(0.074)\end{array}$ & $\begin{array}{c}-0.045^{*} \\
(0.020)\end{array}$ \\
\hline Poor social capital & $\begin{array}{c}0.103 \\
(0.076) \\
\end{array}$ & $\begin{array}{c}0.105 \\
(0.076) \\
\end{array}$ & - & - \\
\hline
\end{tabular}


Table 2: Probit Estimates (continued)

\begin{tabular}{|c|c|c|c|c|}
\hline Expected Recidivism & (1) & (2) & (3) & $\begin{array}{c}\left(3^{\prime}\right) \\
(\mathrm{dF} / \mathrm{dx})\end{array}$ \\
\hline theft $\times$ job & - & $\begin{array}{c}-0.013 \\
(0.170)\end{array}$ & - & - \\
\hline drugs $\times$ job & - & $\begin{array}{c}-0.390^{*} \\
(0.186)\end{array}$ & $\begin{array}{c}-0.364 * \\
(0.179)\end{array}$ & $\begin{array}{c}-0.090^{*} \\
(0.039)\end{array}$ \\
\hline fraud $\times j o b$ & - & $\begin{array}{c}-0.109 \\
(0.194)\end{array}$ & - & - \\
\hline robbery $\times j o b$ & - & $\begin{array}{c}-0.082 \\
(0.209)\end{array}$ & - & - \\
\hline theft $\times$ abitur & - & $\begin{array}{c}0.932 * * \\
(0.361)\end{array}$ & $\begin{array}{l}0.823 * \\
(0.347)\end{array}$ & $\begin{array}{l}0.272^{*} \\
(0.114)\end{array}$ \\
\hline drugs $\times$ abitur & - & $\begin{array}{c}-0.151 \\
(0.366)\end{array}$ & - & - \\
\hline fraud $\times$ abitur & - & $\begin{array}{c}-0.041 \\
(0.331)\end{array}$ & - & - \\
\hline robbery $\times$ abitur & - & $\begin{array}{c}-0.805 \\
(0.541)\end{array}$ & - & - \\
\hline Constant & $\begin{array}{l}-1.145 \\
(0.200)\end{array}$ & $\begin{array}{c}-1.194 \\
(0.202)\end{array}$ & $\begin{array}{l}-1.201 \\
(0.133)\end{array}$ & - \\
\hline Number of observations & 1568 & 1568 & 1568 & 1568 \\
\hline Log likelihood & -782.1 & -778.4 & -801.33 & -801.33 \\
\hline Pseudo R2 & 0.099 & 0.105 & 0.100 & 0.100 \\
\hline
\end{tabular}

Note: (Robust) Standard errors in parentheses, ${ }^{* *}$ and $*$ denote significance at conventional $1 \%$ and $5 \%$ significance levels. $\mathrm{dF} / \mathrm{dx}$ represents average marginal effects (calculated as responses to discrete changes of dummy variables from 0 to 1 ). 
Table 3: Expected Recidivism by Crime Category (Probit Results)

\begin{tabular}{|c|c|c|c|c|c|c|c|}
\hline $\begin{array}{l}\text { Expected } \\
\text { Recidivism }\end{array}$ & Theft & Drugs & Fraud & Robbery & Assault & $\begin{array}{c}\text { Murder/ } \\
\text { manslaughter }\end{array}$ & $\begin{array}{c}\text { Sexual } \\
\text { offences }\end{array}$ \\
\hline Job expectation & $\begin{array}{l}-0.460^{*} \\
(0.216)\end{array}$ & $\begin{array}{c}-1.067 * * \\
(0.261)\end{array}$ & $\begin{array}{l}-0.444^{*} \\
(0.205)\end{array}$ & & - & $\begin{array}{c}-1.158^{* *} \\
(0.418)\end{array}$ & - \\
\hline Job contacts & $\begin{array}{l}-0.281 \\
(0.168)\end{array}$ & $\begin{array}{l}-0.469^{*} \\
(0.187)\end{array}$ & $\begin{array}{c}-0.497^{*} \\
(0.215)\end{array}$ & $\begin{array}{l}-0.468^{*} \\
(0.212)\end{array}$ & - & - & - \\
\hline Male & - & - & $\begin{array}{l}0.915^{* *} \\
(0.282)\end{array}$ & - & - & $\begin{array}{c}0.824 \\
(0.435)\end{array}$ & - \\
\hline Age & - & - & - & - & $\begin{array}{l}-0.018 \\
(0.010)\end{array}$ & $\begin{array}{l}-0.022 \\
(0.013)\end{array}$ & - \\
\hline 'Abitur' & $\begin{array}{c}0.436 \\
(0.296)\end{array}$ & $\begin{array}{l}-0.468 \\
(0.286)\end{array}$ & $\begin{array}{l}-0.559^{*} \\
(0.238)\end{array}$ & $\begin{array}{l}-0.691 \\
(0.425)\end{array}$ & - & - & - \\
\hline $\begin{array}{l}\text { Alcohol/drugs } \\
\text { addiction }\end{array}$ & $\begin{array}{c}0.475^{* *} \\
(0.141)\end{array}$ & $\begin{array}{c}0.574 * * \\
(0.155)\end{array}$ & - & $\begin{array}{c}0.485^{* *} \\
(0.184)\end{array}$ & $\begin{array}{c}0.605^{* *} \\
(0.163)\end{array}$ & $\begin{array}{c}0.771^{* *} \\
(0.262)\end{array}$ & - \\
\hline $\begin{array}{l}\text { Additional crime } \\
=\text { drug dealing/ } \\
\text { consumption }\end{array}$ & $\begin{array}{c}0.510^{* *} \\
(0.172)\end{array}$ & - & $\begin{array}{l}1.074 * * \\
(0.288)\end{array}$ & $\begin{array}{l}0.571^{*} \\
(0.238)\end{array}$ & $\begin{array}{c}0.548 * * \\
(0.195)\end{array}$ & $\begin{array}{c}1.906 * * \\
(0.745)\end{array}$ & - \\
\hline $\begin{array}{l}\text { Additional crime } \\
=\text { fraud }\end{array}$ & - & $\begin{array}{l}0.642 * \\
(0.272)\end{array}$ & - & - & - & - & \\
\hline $\begin{array}{l}\text { Additional crime } \\
=\text { robbery }\end{array}$ & - & $\begin{array}{c}0.468 \\
(0.284)\end{array}$ & - & - & - & - & - \\
\hline $\begin{array}{l}\text { Criminal family } \\
\text { background }\end{array}$ & - & - & - & - & $\begin{array}{l}0.336^{*} \\
(0.175)\end{array}$ & - & - \\
\hline $\begin{array}{l}\text { Frequent contact } \\
\text { with partner }\end{array}$ &.- & - & - & - & $\begin{array}{l}-0.264 \\
(0.161)\end{array}$ & - & - \\
\hline $\begin{array}{l}\text { Poor social } \\
\text { capital }\end{array}$ & - & - & $\begin{array}{l}0.350^{*} \\
(0.172)\end{array}$ & - & $\begin{array}{c}0.275 \\
(0.163)\end{array}$ & - & \\
\hline Constant & $\begin{array}{r}-0.647 \\
(0.114) \\
\end{array}$ & $\begin{array}{r}-0.557 \\
(0.137) \\
\end{array}$ & $\begin{array}{l}-1.609 \\
(0.290) \\
\end{array}$ & $\begin{array}{l}-0.721 \\
(0.140) \\
\end{array}$ & $\begin{array}{l}-0.526 \\
(0.309) \\
\end{array}$ & $\begin{array}{l}-1.050 \\
(0.665) \\
\end{array}$ & $\begin{array}{l}-0.980 \\
(0.117) \\
\end{array}$ \\
\hline $\begin{array}{l}\text { Number of } \\
\text { observations }\end{array}$ & 399 & 329 & 321 & 236 & 314 & 152 & 165 \\
\hline Log likelihood & -237.26 & -184.16 & -145.99 & -129.16 & -173.11 & -66.14 & -73.53 \\
\hline Pseudo R2 & 0.076 & 0.127 & 0.133 & 0.083 & 0.112 & 0.194 & 0.000 \\
\hline
\end{tabular}

Note: (Robust) Standard errors in parentheses, ${ }^{* *}$ and $*$ denote significance at conventional $1 \%$ and $5 \%$ significance levels. $\mathrm{dF} / \mathrm{dx}$ represents marginal values; they are calculated as a discrete change from 0 to 1 in case of explanatory dummy variables. Regression results are included when p-values on included parameters are below 10\% (Abitur: if p-value is below 15\%) 


\section{Conclusions}

Economists tend to believe that good labour market opportunities should prevent criminal behaviour. Testing this hypothesis is difficult and suffers from a lack of adequate (micro) data. A survey of the literature shows that evidence from time series might be flawed due to the problem of misspecification and some omitted variable bias. This article tests the labour market - crime nexus using individual data from a survey of prison inmates. The paper focuses on future behaviour of inmates and tests the hypothesis that labour market prospects (after release from prison) are related to recidivism. Data used to test the hypothesis origin from a prison survey of 1,771 inmates. The survey was conducted in 31 German prisons during the time period 2003 to 2004 . Results confirm the hypothesis that inmates with adverse labour market prospects expect own future recidivism with a significantly higher probability than inmates with good labour market expectations.

Having a closer look at subgroups of prisoners reveals that in particular drug and alcohol addiction provides strong incentives to revive old customs. Moreover, criminals convicted of property crimes report a higher responsiveness to labour market opportunities. As good labour market opportunities are crucial for future legal careers but deteriorated by alcohol or drug problems, improving health care by installing effective anti-drug programmes would be one of the most effective measures against crime.

\section{References}

Ai, C., E.C. Norton (2003): Interaction Terms in Logit and Probit Models. Economics Letters 80, 123129.

Becker, G. S. (1968): Crime and Punishment: An Economic Approach. Journal of Political Economy $76,169-217$

Chiricos, T. G. (1987): Rates of Crime and Unemployment: An Analysis of Aggregate Research Evidence. Social Problems 34, 187-212

Coleman, J. S. (1988): Social capital in the creation of human capital. American Journal of Sociology 94, $95-120$

Eide, E. (1994): Economics of Criminal Behaviour: Deterrence and the Rational Offender. NorthHolland, Amsterdam

Eide, E. (2000): Economics of Criminal Behavior. In: Bouckaert, B., De Geests, G. (Eds.): Encyclopedia of Law and Economics, Vol. V. Cheltenham, Edward Elgar, 345-389

Entorf, H., H. Spengler (2000): Socio-economic and Demographic Factors of Crime in Germany: Evidence from Panel Data of the German States. International Review of Law and Economics 20, 75-106 
Entorf, H., H. Spengler (2002): Crime in Europe: Causes and Consequences. Heidelberg: SpringerVerlag.

Entorf, H., P. Winker (2008): Investigating the Drugs-Crime Channel in Economics of Crime Models: Evidence from Panel Data of the German States. International Review of Law and Economics, 28(1), 8-22.

Entorf, H., S. Meyer, J. Moebert (2008): Evaluation des Justizvollzugs. Ergebnisse einer bundesweiten Feldstudie. Heidelberg: Physica-Verlag.

Franz, W. (1982): An Economic Analysis of Female Work Participation, Education, and Fertility: Theory and Evidence for the Federal Republic of Germany. Journal of Labor Economics 3(2), S218-S234.

Freeman, R. B. (1995): The Labor Market. In: Wilson, J. Q., Petersilia, J. (Eds.): Crime. ICS Press, San Francisco, 171-191

Freeman, R. B., Holzer, H. J. (1986): The Black Youth Employment Crisis. University of Chicago Press, Chicago (IL).

Good, D.H., M.A. Pirog-Good (1987): Employment, Crime and Race. Contemporary Economic Policy 5(4), 91-104.

Hirschi, T. (1969): Causes of Delinquency. University of California Press, Berkely (CA)

Hirschi, T. (1995): The Family. In: Wilson, J. Q., Petersilia, J. (Eds.): Crime. ICS Press, San Francisco, 121-140

Holzman, H. R. (1983): The Serious Habitual Property Offender as "Moonlighter": An Empirical Study of Labor Force Participation Among Robbers and Burglars. Journal of Criminal Law \& Criminology 73, 1774-1792

Junger-Tas, J. (1992): An Empirical Test of Social Control Theory. Journal of Quantitative Criminology 8, 9-28.

Knack, S., P. Keefer (1997): Does Social Capital Have an Economic Pay-Off? A Cross-Country Investigation. Quarterly Journal of Economics 112, 1251-1288.

Lin, M.-J. (2008): Does Unemployment Increase Crime? Evidence from U.S. Data 1974 - 2000. Journal of Human Resources 43(2), 413-436.

Lochner, L. (2004): Education, Work, and Crime: A Human Capital Approach. International Economic Review 45(3), 811-843

Löwe, A. (1914): Arbeitslosigkeit und Kriminalität. Eine kriminologische Untersuchung. In: F. von Liszt and E. Delaquis (Eds.), Abhandlungen des kriminalistischen Instituts an der Universität Berlin, Berlin.

Meyer, S. (2005): Codebuch zur Umfrage 2003/2004 im Projekt 'Kosten und Nutzen von Haft und Haftvermeidung'. Darmstadt University of Technology; downloadable: vwl.tudarmstadt.de/vwl2/papers/vw-codebook.pdf

Meyer, S. (2007a): Sozialkapital und Delinquenz - Eine empirische Untersuchung für Deutschland. Ph.D. thesis, Darmstadt University of Technology, Darmstadt.

Meyer, S. (2007b): Lebenslagen straffällig gewordener Menschen. Sonderauswertung der Bundesarbeitsgemeinschaft für Straffälligenhilfe e.V., Bonn, downloadable: http://www.bagstraffaelligenhilfe.de/pdf/sonderauswertung.pdf.

Putnam, R. (1993): Making Democracy Work: Civic Traditions in Modern Italy. Princeton: Princeton University Press.

Putnam, R. (2000): 'Bowling alone': The Collapse and Revival of American Community. New York: Simon and Schuster. 
Raphael, S., R. Winter-Ebmer (2001): Identifying the Effect of Unemployment on Crime. Journal of Law and Economics, 44(1), 259-283.

Rupp, T. (2008): Meta Analysis of Crime and Deterrence: A Comprehensive Review of the Literature. Ph.D. Thesis, Darmstadt University of Technology, Norderstedt: Books on Demand.

Shaw, C., McKay, H. (1942 / 1969, revised Edition): Juvenile Delinquency and Urban Areas. University of Chicago Press, Chicago (IL)

Sutherland, E. H. (1942 / 1973, revised Edition): Development of the Theory. Private Paper Published Posthoumosly in Schuessler, K. (Ed.): Edwin Sutherland on Analyzing Crime. Chicago University Press, Chicago (IL), 30-41

Sviridoff, V., Thompson, J. W. (1983): Links Between Employment and Crime: A Qualitative Study of Rikers Island Releases. Crime and Delinquency 29, 195-212

Tauchen, H., Witte, A. D., Griesinger, H. (1994): Criminal Deterrence: Revisiting the Issue with a Birth Cohort. Review of Economics and Statistics 76, 399-412

Thornberry, T. P. (1996): Empirical Support for Interactional Theory: A Review of the Literature. In: Hawkins, J. D. (Ed.): Some Current Theories of Crime and Deviance. Cambridge University Press, New York, 198-235

Thornberry, T. P., Krohn, M. D., Lizotte, A. J., Chard-Wierschem, D. (1993): The Role of Juvenile Gangs in Facilitating Delinquent Behavior. Journal of Research in Crime and Delinquency 30, 5587

Viscusi, W. K. (1986): Market Incentives for Criminal Behavior. In: Freeman, R. B., Holzer, H. (Eds.): The Black Youth Employment Crisis. University of Chicago Press, Chicago (IL)

Weinberg, B., E. Gould, D.B. Mustard (2002): Crime Rates and Local Labour Market Opportunities in the United States: 1979-1997. Review and Economics and Statistics 84(1), 45-61.

Williams, J., Sickles, R. C. (2000): An Intertemporal Model of Rational Criminal Choice. Paper presented at the World Congress of the Econometric Society, Seattle (WA), 11-16 August 2000 